\title{
ARQUIVOS, IMAGENS E PERCURSOS EM ABLATIVO
}

\section{Monique Bione* \\ Universidade Federal de Santa Catarina}

A poesia é tudo aquilo que não cabe dentro do poeta, essa afirmação foi confidenciada certa vez pelo escritor paraibano Ariano Suassuna e essa seria uma das inúmeras interpretações que poderíamos implicar ao pensar a poesia; contudo, a poesia se faz e se define a partir daqueles que a criam; "é um organismo que se funda sobre a percepção de limites e terminações"1 como bem explicita o filósofo Giorgio Agamben. Por que a importância da poesia? Talvez por fazer parte de nós como as poesias drummonianas autobiográficas. E, neste caso, autobiográficas não apenas para o poeta que as construiu, mas para cada um que as lê na sua divergente unicidade. Uma vez mais empresto as palavras de Agamben quando diz que "Poeta é quem, na palavra, gera a vida. A vida que o poeta gera na palavra é subtraída tanto da vivência do indivíduo psicossomático quanto da indivisibilidade biológica do gênero" (2011, p. 32) para chegar a outro italiano, Enrico Testa, na sua edição bilíngue recém-lançada no Brasil por Rafael Copetti Editor, Ablativo; onde a vida é "materializada" em palavras, num apanhado de impressões e sentimentos retirados do arquivo do próprio poeta como aponta Patricia Peterle no posfácio do referido exemplar.

Enrico Testa volta-se para si mesmo, no encadeamento de suas frases, numa leveza por vezes irônica, segue despertando ou fazendo-se despertar os sentidos "banais" do cotidiano. Nossos olhos, descomedidamente paralisados e estagnados no comum, que não

BY No ND Esta obra está licenciada sob uma Licença Creative Commons.

\footnotetext{
* Mestranda em Literatura pela Universidade Federal de Santa Catarina. Possui graduação em Jornalismo pelo Instituto Superior e Centro Educacional Luterano Bom Jesus (2011). Atualmente é escritora, revisora da revista Caminho Aberto do Instituto Federal de Educação Ciência e Tecnologia de Santa Catarina (IFSC) e tutora presencial do curso de pós-graduação em Gestão Pública também pelo IFSC. Participa do projeto Dicionário Bibliográfico da Literatura Italiana Traduzida no Brasil (1900-1950), o qual é desenvolvido por pesquisadores da UFSC/USP. Tem experiência na área de Comunicação e Letras, com ênfase em Língua Portuguesa e Literatura, atuando principalmente nos seguintes temas: literatura, poesia brasileira e italiana, fotografia, cultura, mídias e jornalismo. E-mail: nickbione@,hotmail.com.

${ }_{1}^{1}$ AGAMBEN, Giogio. La fine del poema. In: Giorgio Agamben. Categorie italiane. Studi di poetica. Venezia: Marsilio, 1966, p. 143. Tradução de Sérgio Alcides.
} 
veem diante de si nem a si mesmos. Folhear as páginas do Ablativo é ter a oportunidade, se assim nos permitirmos, de retirar a fina camada adormecida de comodismo pousada nesses mesmos olhos. A poesia não deve ser escrita nas suas formas românticas, doces e demasiadamente usuais, mas através de alguém que é espectador da própria vida; “descreva tudo isso com sinceridade íntima, serena, paciente, e utilize, para se expressar, as coisas de seu ambiente, as imagens de seus sonhos e os objetos de suas lembranças" (RILKE, 2009, p. 23), conselho dado por Rilke é demonstrado na coletânea dos oitenta e dois poemas desse premiado poeta genovês, Enrico Testa.

Ablativo é o resultado de um competente trabalho de tradução realizado em conjunto pelos professores Patricia Peterle, Silvana de Gaspari e Andrea Saturbano; proporcionando aos leitores brasileiros, apaixonados por poesia, uma viagem nos arquivos da memória de um poeta que percebe, por entre o véu do frenético cotidiano da contemporaneidade, os rastros sutis que compõem rizomas - na teoria filosófica de Deleuze e Guattari - entre poesia e vida.

A obra é composta de onze seções, intituladas: "No sono", "Trópico do Escorpião", "Plataforma 20", "Viagem da sombra", "Cais de Alcântara", "Naufrágios", "Balcânicas", "A ceifadeira", "Gramática", "Breve excursão pela América do Sul" e "Passagem", respectivamente.

Esse poeta viajante percorre lugares de infância e de experiências provadas para evidenciar o lugar-comum que habita tudo que se encontra em suspenso, em "estado de cegueira" e "na qual não é possível ver com mais clareza". Percebe-se tal intenção no primeiro poema do volume: "de oração em oração/ e de esperança em esperança / (grandes como pulgas, mas petulantes) / acabamos nesta neblina / que esconde armadilhas e penhascos" (2014, p. 11). O tom reflexivo de Testa passeia por entre o humor cortante e a crítica social em que a incerteza da salvação reside na esperança fugaz, como em "Trópico de escorpião", e nos remete a um vivo diálogo com a tradição poética italiana da qual integra Giorgio Caproni e Eugenio Montale.

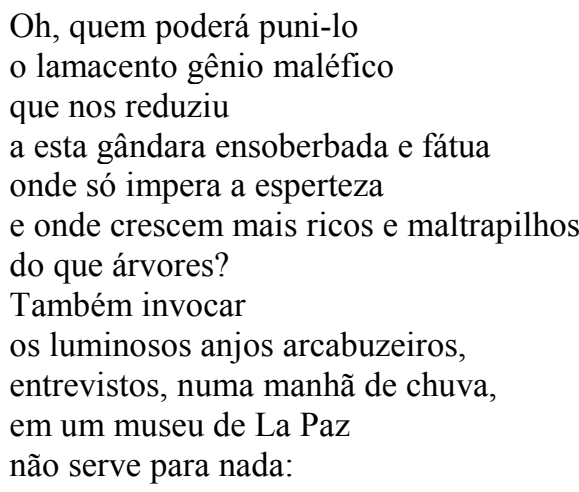


têm pólvoras molhadas

como as nossas pobres bandeiras. (TESTA, 2014, p. 47)

No trecho, acima citado, o desconforto diante da vida é tanto que até os "anjos arcabuzeiros" não servem para nada na luta diária entre o bem e o mal. Esse tom incômodo acompanha Testa por toda a obra e a sua linguagem é a ferramenta primordial para pensar o enigma da vida.

A ironia dos trocadilhos do poeta foi preservada numa preocupada tradução para manter a sua originalidade como no caso das palavras "DIAMOX" e "DIOMAX" de "Breve excursão pela América do Sul"; curiosamente o Diamox é um medicamento diurético e Testa faz um trocadilho com "DIOMAX", outro termo mantido que, numa tradução literal, seria DEUSMAX.

Ao percorrermos Ablativo, viajamos entre poesias que sibilam entre o cheio e o vazio, entre páginas encorpadas e miúdas, como "homens-formigas" de "Breve excursão pela América do Sul”. Deparamo-nos ainda com a oscilação anacrônica entre luz, sombra e tantos outros antagonismos inquietantes que observamos ao embarcarmos nessa viagem com Testa; a mesma inquietude diante do mundo provada por Drummond e Montale.

Ablativo nos propõe o mesmo que o significado desta palavra carrega em si, na sua derivação do verbo latino, ou seja, movimento e complementariedade. É o passeio polivalente que o olhar do poeta genovês faz nos seus versos prosaicos que trazem à tona a ambivalência do Eu no mundo, adquirido de uma vasta experiência nas mais diversas paisagens culturais. Ao deslocar-se no mundo, Testa desloca também as palavras, numa dança de desagregações e sentidos, como quando diz "argila rostos sal". O poeta lança mão das palavras "pois não temos outros instrumentos além das palavras, que permanecem nossos mestres em todas as coisas / Já que é necessário fazer uso delas para se calar" (2011, p. 18) bem como expõe Maurice Blanchot em Uma voz vinda de outro lugar. A poesia "dá voz à existência simultânea, aos tempos do Tempo, que ela invoca, evoca, provoca" (BOSI, 1977, p. 120) e Testa faz do espaço poético experimentação fugaz e a compartilha conosco.

[Recebido em fevereiro de 2015 e aceito para publicação em junho de 2015]

\section{Referências}

AGAMBEN, Giorgio. A coisa perdida: Agamben comenta Caproni. Aurora Fornini Bernadini, organização e tradução. Florianópolis: EdUFSC, 2011. 
BLANCHOT, Maurice. Uma voz vinda de outro lugar. Trad. de Adriana Lisboa. Rio de Janeiro: Rocco, 2011.

BOSI, Alfredo. O ser e o tempo da poesia. São Paulo: Cultrix Ed. da Universidade de São Paulo, 1977.

TESTA, Enrico. Ablativo. Trad. de Patricia Peterle, Silvana de Gaspari e Andrea Saturbano. São Paulo: Rafael Copetti Editor, 2014.

RILKE, Rainer Maria. Cartas a um jovem poeta. Trad. de Pedro Süssekind. Porto Alegre: L\&PM, 2009. 